УДК 547.918

\title{
ДИНАМИКА НАКОПЛЕНИЯ СТЕРОИДНЫХ ВЕЩЕСТВ В HELLEBORUS CAUCASICUS A.BR.
}

\section{() Т.С. Музашвили}

\author{
Институт фрармакохимии им. И.Г. Кутателадзе, ул. П. Сараджишвили, 36, \\ Тбилиси, 0159 (Грузия), e-mail: tamar.muzashvili@gmail.com
}

\begin{abstract}
Изучена динамика накопления суммы стероидов в подземных органах и листьях морозника кавказского Helleborus caucasicus A.Br. в течение вегетации растения. Установлено что их максимальное содержание в подземных частях (11\%) наблюдается в сентябре - октябре, а в листьях $(10,5 \%),-$ в апреле, в период бурного цветения растения. Полученные данные следует принимать во внимание при заготовке качественного сырья.

Ключевые слова: морозник кавказский, стероидные вещества, подземные органы, листья.
\end{abstract}

Работа выполнена при финансовой поддержке Грузинского наиионального фонда науки им. Ш. Руставели (грант №GNSF/2-6/30).

Широко распространенный в Грузии эндемичный вид для Кавказа - морозник кавказский (Helleborus caucasicus A.Br.) - богат стероидами. Из подземных частей и листьев растения изолированы и охарактеризованы: буфадиенолиды, экдистероиды, 13 фуро- и спиростаноловых гликозидов, в основном производные полигидрокси- и полиненасыщенных агликонов - так называемые «кавказикозиды А-М», впервые описанные нами $[1,2]$.

В представленной работе приведены данные по изучению динамики накопления суммы стероидов в подземных органах и листьях морозника кавказского в течение вегетации растения. Объектами исследования явились образцы, собранные в окрестностях Тбилиси (с. Патара Дидгори) в 2009-2010 гг. в 25-28 числах каждого месяца.

Количество стероидных веществ определяли весовым методом - по их выходу из растения. 100 г воздушно-сухих измельченных корневищ с корнями экстрагировали петролейным эфиром в аппарате Сокслета; обезжиренное сырье трижды экстрагировали 80\%-м метанолом. Объединенные экстракты фильтровали, спирт отгоняли, водную фазу извлекали $н$-бутанолом. Бутанольные извлечения сгущали до полного удаления сольвента, остатки сушили в вакуумной сушилке при $45{ }^{\circ} \mathrm{C}$ и взвешивали. 100 г воздушносухих измельченных листьев извлекали 80\%-м метанолом трехкратно при температуре кипения растворителя. Объединенные экстракты фильтровали, спирт отгоняли, водную фазу очищали хлороформом и извлекали $н$-бутанолом. Бутанольные извлечения обрабатывали, как в случае подземных частей. Полученные данные приведены в таблице и на рисунке.

Качественный состав отдельных образцов анализировали тонкослойным хроматографированием на пластинках силикагеля Adamant $\mathrm{F}_{254}$ в системе: хлороформ - метанол - вода $(26: 14: 3)$. На хроматограммах стероиды обнаруживали реактивами Эрлиха и Санье. Морозник кавказский имеет длительный период бутонизации и цветения и двухкратное созревание семян. По-видимому, это и обусловливает колебание в накоплении стероидов в органах растения.

Как видно из таблицы и диаграммы, содержание стероидов в подземных частях и листьях самое низкое в период первого созревания семян в мае - июле; с августа наблюдается тенденция их повышения, максимум (11\%) достигается в подземных органах в сентябре - октябре. Сравнительно высокий уровень стероидов в них

Музашвили Тамара Сергеевна - научный сотрудник, кандидат фармацевтических наук, e-mail: tamar.muzashvili@gmail.com сохраняется в ноябре - декабре $(9,7-9,3 \%)$ и резкое падение содержания наблюдается в январе (7\%), а с февраля вновь повышается и до апреля держится на 8,3\%. 
Содержание стероидных веществ в подземных органах и листьях морозника кавказского по месяцам, \% (средние показатели из двухлетних наблюдений)

\begin{tabular}{l|c|c|c|c|c|c|c|c|c|c|c|c}
\hline Месяцы & I & II & III & IV & V & VI & VII & VIII & IX & X & XI & XII \\
\hline Корнаны & & & & & & & & & & & & \\
Листья & 7,0 & 8,3 & 8,3 & 8,3 & 7,3 & 7,3 & 7,7 & 8,3 & 11,0 & 11,0 & 9,7 & 9,3 \\
\hline
\end{tabular}

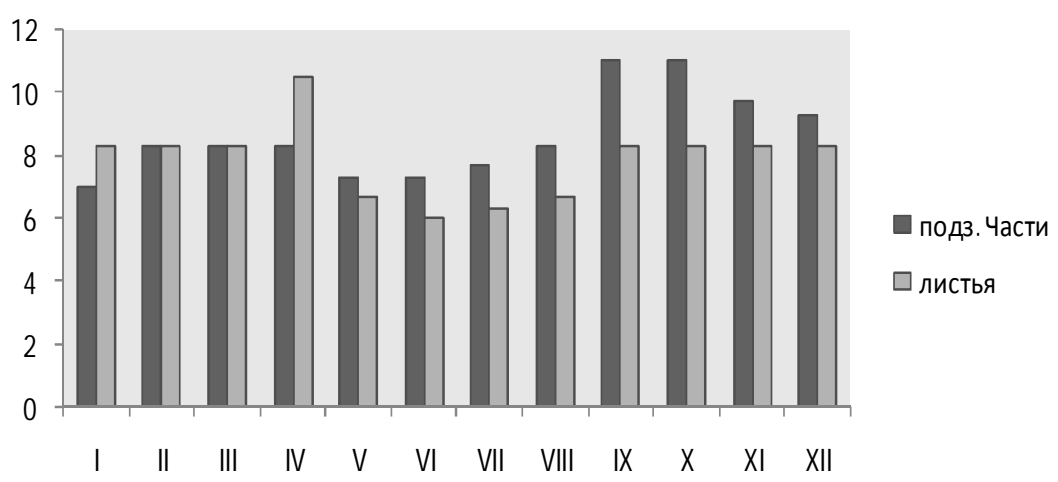

\author{
Диаграмма динамики \\ накопления стероидов в \\ морознике кавказском
}

В листьях с сентября до марта отмечается одинаковое содержание - 8,3\%, а самое высокое - 10,5\% в апреле - в период бурного цветения растения.

Обращает на себя внимание то обстоятельство, что в корнях и корневищах качественный состав стероидов также более богат осенью - в образцах, заготовленных в сентябре - ноябре, на ТСХ проявляются интенсивные пятна фуро- и спиростаноловых гликозидов. Качественный состав листьев в течение года почти не меняется; исключение составляют экдистероиды, которых значительно больше в феврале - мае.

Полученные данные следует принимать во внимание при заготовке качественного сырья.

\title{
Сиисок литературы
}

1. Bassarello C., Muzashvili T., Skhirtladze A., Kemertelidze E., Pizza C., Piacente S. Steroidal glycosides from the underground parts of Helleborus caucasicus // Phytochemistry. 2008. Vol. 69. Pp. 1227-1233.

2. Muzashvili T., Perrone A., Napolitano A., Kemertelidze E., Pizza C., Piacente S. Caucasicosides E-M, furostanol glycosides from Helleborus caucasicus // Phytochemistry. 2011. Vol. 72, N17. Pp. 2180-2188.

Поступило в редакичию 8 июня 2012 2.

После переработки 22 сентября 2013 г.

Muzashvili T.S. DYNAMICS OF STEROIDAL COMPOUNDS ACCUMULATION IN HELLEBORUS CAUCASICUS A.BR.

Institute of Pharmaceutical Chemistry I.G. Kutateladze, P. Saradzhishvili st., 36, Tbilisi, 0159 (Georgia),

e-mail: tamar.muzashvili@gmail.com

Dynamics of steroidal compounds accumulation in underground parts and leaves of Helleborus caucasicus A.Br. has been studied during the plant vegetation period. Their maximal concentration in underground parts (11\%) in September - October was observed, while in the leaves $(10,5 \%)$ in April. The obtained data should be taken into account when collecting the plant material.

Keywords: Helleborus caucasicus A.Br., steroidal compounds, underground parts, leaves.

\section{References}

1. Bassarello C., Muzashvili T., Skhirtladze A., Kemertelidze E., Pizza C., Piacente S. Phytochemistry, 2008, vol. 69, pp. 1227-1233.

2. Muzashvili T., Perrone A., Napolitano A., Kemertelidze E., Pizza C., Piacente S. Phytochemistry, 2011, vol. 72, no. 17 , pp. 2180-2188.

Received June 8, 2012

Revised September 22, 2013 